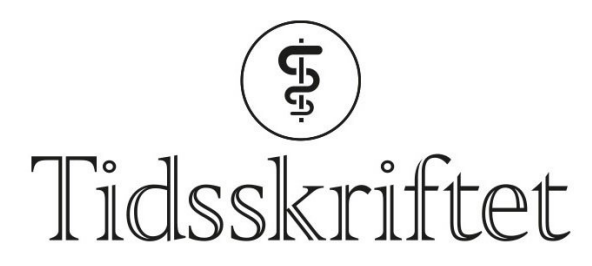

DEN NORSKE LEGEFORENING

\title{
Vil kjennskap til interessekonflikter påvirke fagfellevurderinger?
}

FRA ANDRE TIDSSKRIFTER

KETIL SLAGSTAD

Tidsskriftet

Kjennskap til forfatternes interessekonflikter ser ikke ut til å påvirke fagfellevurderinger av vitenskapelige manuskripter.

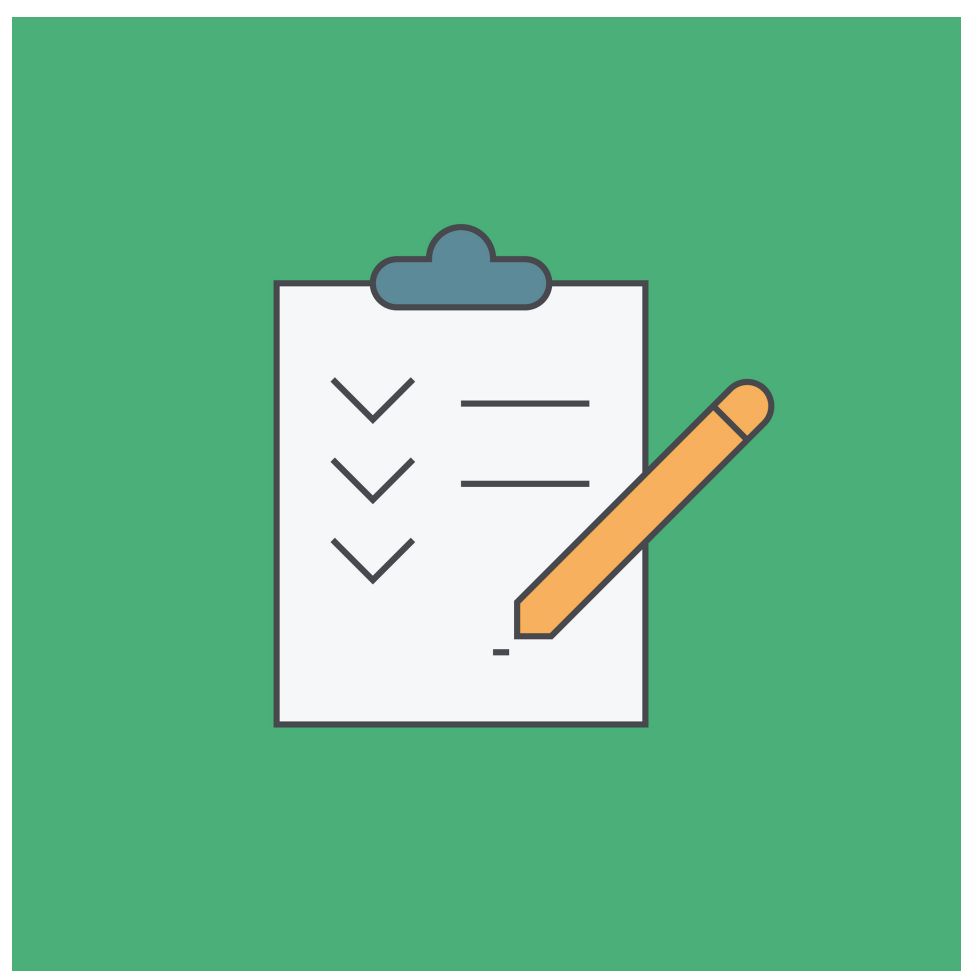

Illustrasjon: Vipul Umretiya / iStock

De fleste medisinske tidsskrifter, også Tidsskriftet, krever at forfattere av innsendte manuskripter fyller ut et interessekonfliktskjema. Det er imidlertid gjort lite forskning på hvordan disse skjemaene påvirker fagfellenes vurderinger.

I en studie som nylig er publisert i BMJ, ble fagfellevurderere i et anerkjent medisinsk tidsskrift randomisert til enten å motta eller ikke motta interessekonfliktskjemaene til forfatterne av manuskriptet de skulle vurdere. Studien omfattet 800 fagfellevurderere for rundt 1500 manuskripter innsendt i perioden juni 2014-18 (1). Redaktørene av tidsskriftet var ikke informert om studien. 
Kvaliteten på manuskriptene ble vurdert likt av dem som hadde mottatt interessekonfliktskjema og dem som ikke hadde mottatt dette. Nesten $80 \%$ av fagfellevurdererne som hadde mottatt skjema, oppga at de husket at de hadde fått det. De ble deretter bedt om å gi manuskriptene en ny skår gitt at de hadde blitt randomisert til den andre gruppen av fagfellevurderere. Skårene ved dette tankeeksperimentet avvek ikke fra opprinnelig skår. Selv om fagfellevurdererne anså interessekonflikter som viktige, og at de ville justere for interessekonflikter i fagfellevurderingen, viste resultatene i denne studien det motsatte.

- Selv om fagfeller ikke er representative for alle lesere, tror jeg disse funnene kan si noe mer generelt om hvordan kjennskap til interessekonflikter påvirker lesing av forskningsartikler, sier Magnus Løberg, som er førsteamanuensis ved Institutt for helse og samfunn ved Universitetet i Oslo. Han synes ikke det er så rart at kvalitetsvurderingen ikke ble påvirket av kjennskap til interessekonflikter. - Kvalitet blir ofte forbundet med en objektiv vurdering av om noe er gjort riktig eller galt. Kanskje er det heller troverdigheten som blir påvirket av kjennskap til interessekonflikter, sier Løberg.

- Åpenhet og transparens om interessekonflikter er helt nødvendig for troverdighet i forskning, men er sjelden tilstrekkelig, sier Løberg. Han mener at vi må bli bedre til å håndtere interessekonflikter innen publisering, retningslinjearbeid og kliniske beslutninger.

\section{LITTERATUR:}

1. John LK, Loewenstein G, Marder A et al. Effect of revealing authors' conflicts of interests in peer review: randomized controlled trial. BMJ 2019;367: 15896. [PubMed][CrossRef]

Publisert: 24. februar 2020. Tidsskr Nor Legeforen. DOI: 10.4045/tidsskr.20.00o8

(C) Tidsskrift for Den norske legeforening 2020. Lastet ned fra tidsskriftet.no 